\title{
KOMPARASI METODE DWT DAN SVD UNTUK MENGUKUR KUALITAS CITRA STEGANOGRAFI
}

\author{
Dedi Darwis $^{1)}$, A. Ferico Octaviansyah Pasaribu ${ }^{2)}$ \\ 1), 2) Fakultas Teknik dan Ilmu Komputer, Universitas Teknokrat Indonesia \\ Jl Zainal Abidin Pagar Alam No 9-11 Labuhan Ratu, Bandar Lampung \\ Email :darwisdedi@teknokrat.ac.id ${ }^{1}$, fericopasaribu@teknokrat.ac.id ${ }^{2}$
}

\begin{abstract}
Abstrak
Keamanan data saat ini merupakan hal yang sangat penting diera digital karena komunikasi harus bersifat rahasia dan aman. Salah satu cara untuk berkomunikasi secara digital adalah steganografi yaitu pengembangan dari kriptografi, teknik ini memiliki cara menyembunyikan data dan informasi pada media lainnya misalkan seperti citra digital karena media ini sering digunakan dalam pertukaran informasi dan data. Algoritma steganografi yang digunakan pada penelitian ini adalah Discrete Wavelet Transform (DWT) dan Singular Value Decomposition (SVD) kedua metode ini merupakan bagian dari steganografi yang sama-sama memanfaatkan domain transform pada pengolahan citra digital dan memiliki kecepatan yang tinggi dalam penyisipan pesan rahasia ke suatu gambar. Masalah yang selama ini terjadi pada steganografi adalah kualitas stego image yang dihasilkan pada steganografi mengalami perubahan pada kualitas citra, sehingga perbedaan antara cover image dan stego image akan sangat terlihat. Penerapan metode DWT dan SVD pada penelitian ini diimplementasikan dengan bahasa pemrograman Python 3. Berdasarkan hasil pengujian yang dilakukan metode DWT dapat menghasilkan kualitas citra pada stego image yang lebih baik jika dibandingkan metode SVD yaitu menghasilkan nilai MSE nilai rata-rata 0,0046 db. Hasil perhitungan nilai PSNR juga membuktikan bahwa metode DWT menghasilkan kualitas citra lebih baik dari dari metode SVD yaitu menghasilkan nilai rata-rata 63,47 db.
\end{abstract}

Kata kunci: DWT, Steganografi, Stego image, SVD

\begin{abstract}
Data security is currently very important in the digital era because communication must be confidential and secure. One way to communicate digitally is steganography, which is the development of cryptography, this technique has a way of hiding data and information in other media, for example, such as digital images because this media is often used in exchanging information and data. The steganographic algorithms used in this study are Discrete Wavelet Transform (DWT) and Singular Value Decomposition (SVD). Both of these methods are part of steganography which both use domain transform in digital image processing and have high speed in inserting secret messages into a picture. The problem that has occurred in steganography is that the quality of the stego image produced in steganography changes in image quality, so that the difference between the cover image and the stego image will be very visible. The application of the DWT and SVD methods in this study is implemented with the Python 3 programming language. Based on the results of the tests carried out by the DWT method, it can produce better image quality on the stego image when compared to the SVD method, which produces an average MSE value of $0.0046 \mathrm{db}$. The PSNR value calculation results also prove that the DWT method produces better image quality than the SVD method, which produces an average value of $63.47 \mathrm{db}$.
\end{abstract}

Keywords : DWT, Steganography, Stego image, SVD

\section{PENDAHULUAN}

Komunikasi digital adalah sebuah bagian infrastruktur yang sangat mendasar saat ini, banyak aplikasi yang berbasis jaringan internet dan komunikasi data yang ada di dalamnya beberapa memiliki kerahasiaan [1]. Masalah kerahasiaan dan keamanan merupakan komponen penting dari suatu data dan informasi. Pengiriman dan penerimaan data dan informasi melalui jaringan internet memang memiliki banyak kelebihan salah satunya adalah kecepatan dalam proses transmisi, akan tetapi dilain sisi pengiriman melalui jaringan internet mempunyai kelemahan yaitu kejahatan internet (cyber-crime) seperti penyadapan, perubahan data dan lainnya [2, 3]. Media penyimpanan dan penyebaran data atau informasi yang digunakan menjadi salah satu penyebab data atau informasi tersebut mudah diambil oleh pihak yang tidak memiliki legalitas. Hal ini disebabkan karena sistem keamanan data yang kurang baik dalam melindungi kerahasiaan data maupun informasi [4]. Salah satu cara untuk mengamankan data dan 
informasi adalah menggunakan teknik steganografi yaitu merupakan ilmu atau seni untuk menyembunyikan pesan yang melibatkan suatu media yang terdiri dari objek pesan yang disembunyikan dalam suatu media tertentu yang dapat berupa gambar, suara, text dan lain-lain, yang biasa disebut Hidden Message kemudian objek yang kedua terkait dengan media untuk menampung pesan rahasia atau yang disebut cover yang dapat berupa gambar, video, audio dan media lainnya [5, 6, 7].

Pemanfaatan media teknologi dalam mengirim, menyimpan dan mengambil gambar dapat mempengaruhi kualitas gambar. Pertimbangan terhadap penurunan kualitas gambar merupakan salah satu elemen penting yang harus di pertimbangkan dalam memilih metode steganografi yang akan digunakan. Pada penelitian ini akan dilakukan perbandingan dua metode pada steganografi yaitu Discrete Wavelet Transform (DWT) dan Singular Value Decomposition $(S V D)$, kedua metode steganografi tersebut sudah cukup banyak digunakan. DWT merupakan metode yang telah mendapat pengakuan dan popularitas luas dalam pemrosesan gambar [8]. Kemampuannya adalah menangkap energi sinyal dalam beberapa nilai transformasi energi. Dalam denoising DWT hanya dilakukan dalam koefisien detail, hal ini memberikan keuntungan kelancaran dan adaptasi [8,9]. Pada penelitian ini juga menggunakan metode SVD untuk menganalisa perbandingan citra, di mana cara kerja $S V D$ adalah memfaktorisasikan matrik lalu menguraikan matrik nyata atau kompleks $[10,11]$.

Masalah yang selama ini terjadi pada steganografi adalah kualitas stego image yang dihasilkan pada steganografi mengalami perubahan pada kualitas citra, sehingga stego image yang dihasilkan sangat berbeda dengan cover image. Pada penelitian ini, cover gambar yang akan digunakan adalah image dengan format *.png, sedangkan untuk pesan rahasia disimpan dalam file dengan format *.txt. Penelitian ini bertujuan untuk mengukur kualitas citra berdasarkan dua metode steganografi yaitu $D W T$ dan SVD sehingga dapat menjadi alternatif pilihan ketika akan mengimplementasikan metode steganografi.

\section{DASAR TEORI}

\subsection{Penelitian Terkait}

Penelitian dengan judul Robust Image Steganography using Complex Wavelet Transform. Penelitian ini membahas implementasi Discrete Wavelet Transform (DWT) menggunakan filter koefisien nyata yang menghasilkan perkiraan nilai nyata dan detail sinyal input. Complex Wavelet Transform pada awalnya dikembangkan untuk menggabungkan informasi fase melalui penggunaan filter bernilai kompleks yang menguraikan sinyal input menjadi bagian nyata dan imajiner. Singular Value Decomposition merupakan teknik untuk faktorisasi matriks yang menguraikan matriks nyata atau kompleks, $\mathrm{X}$, menjadi produk dari tiga matriks - matriks ortogonal, matriks diagonal S, dan transposasi dari matriks ortogonal V. Hasil eksperimental menunjukkan bahwa teknik yang diusulkan memberikan keamanan dan ketahanan terhadap beberapa pemrosesan gambar umum dan serangan geometris seperti kompresi JPEG, filter low-pass gaussian, filter median, penambahan gaussian noise, cropping, rotasi, pengubahan ukuran dan serangan pemerataan histogram. Metode yang diusulkan jelas mengungguli metode berbasis DWT-SVD yang diusulkan dalam dalam hal kualitas visual dan ketahanan terhadap pemrosesan gambar serta serangan geometris [12].

Penelitian selanjutnya dengan judul A Robust Steganographic Method based on Singular Value Decomposition. Penelitian ini menjelaskan dua catatan untuk nilai Singular Value Decomposotion (SVD) dengan skema watermarking berbasis dekomposisi, yang dapat meningkatkan tembus pandang dan kapasitas yang lebih ketika embedding informasi ke kiri dan kanan vektor singular. Penelitian ini menghasilkan pengembangan metode yang dapat tahan sampai dengan 50\% dari serangan kompresi dan gaussian noise [13].

Perbedaan dari beberapa penelitian terkait dengan penelitian yang dikembangkan adalah berfokus pada metode $D W T$ dan $S V D$ fokus untuk membandingkan kualitas citra yang dihasilkan oleh stego image dengan mengukur nilai MSE dan PSNR.

\section{$2.2 \quad$ Konsep Steganografi}

Steganografi yaitu merupakan ilmu atau seni untuk menyembunyikan pesan yang melibatkan suatu media yang terdiri dari objek pesan yang disembunyikan dalam suatu media 
tertentu yang dapat berupa gambar, suara, text dan lain-lain, yang biasa disebut Hidden Message kemudian objek yang kedua terkait dengan media untuk menampung pesan rahasia atau yang disebut cover yang dapat berupa gambar, video, audio dan media lainnya [14]. Adapun komponen dalam steganografi, diantaranya :

1. Wadah Penampungan

Berupa sebuah gambar bersih yang tidak terlihat mencurigakan.

2. Cover

Dalam stego-image cover berupa sebuah gambar bersih yang tidak terlihat mencurigakan yang akan menjadi carrier untuk pesan yang disembunyikan.

3. Pesan

Sebuah pesan yang dapat disembunyikan dalam cover image yang dapat berupa plain text, chipper text, gambar lain, atau apapun yang dapat disisipkan dalam satuan bit.

4. Stego-Key

Stego-key adalah sebuah tipe password yang juga dapat disembunyikan, ketika kemudian mendecode pesan.

\section{Discrete Wavelet Transform}

Transformasi wavelet (wavalet transform) memiliki kemudahan dalam melakukan compression image, transmision dan image analysis. Wavelet transform berorientasi pada gelombang kecil yaitu 'wavelet'[15].

\section{Singular Value Decomposition}

Singular Value Decomposition (SVD) dikatakan menjadi topik penting dalam aljabar linier oleh banyak matematikawan terkenal. $S V D$ memiliki banyak nilai-nilai praktis dan teoritis. Komponen khusus dari metode $S V D$ yaitu dapat memproses matriks real dengan ordo (m,n) [16]. Misalkan matriks A dengan $\mathbf{m}$ baris dan $\mathbf{n}$ kolom, dengan rentan matriks $\mathbf{r}$ dan $\mathbf{r} \leq \mathbf{n} \leq \mathbf{m}$. Maka, A dapat difaktorisasi menjadi tiga matriks $\boldsymbol{U}, \boldsymbol{S}$ dan $\boldsymbol{V}$ dengan komposisi berikut :

$A_{m n}=U_{m m} S_{m n} V_{n m}^{T}$

Keterangan :

Matriks $\boldsymbol{U}$ adalah matriks orthogonal berodo $\boldsymbol{m} \mathbf{x} \boldsymbol{m}$ yang bersifat :

$\boldsymbol{U}^{T} \boldsymbol{U}=\boldsymbol{I}$.

Matriks $\mathbf{V}$ adalah matriks orthogonal berordo $\boldsymbol{n} \mathbf{x} \boldsymbol{n}$ yang bersifat :

$V^{T} V=I$.

Kolom dari $\boldsymbol{U}$ adalah eigenvector orthogonal dari $\boldsymbol{A A}^{T}$

Kolom dari $\boldsymbol{V}$ adalah eigenvector orthogonal dari $\boldsymbol{A}^{T} \boldsymbol{A}$

$\mathbf{S}$ adalah matriks diagonal yang berisi akar eigenvalue dari $\boldsymbol{U}$ atau $\boldsymbol{V}$ yang disusun secara urut dari besar hingga lebih kecil.

\section{METODOLOGI PENELITIAN}

Pada penelitian yang dilakukan, tahapan awal adalah melakukan kajian literatur yaitu melalui jurnal dan buku referensi sebagai acuan dalam mempelajari metode $D W T$ dan $S V D$. Setelah itu mengumpulkan sebanyak 5 gambar sekunder yang diambil dari penelitian sebelumnya [17]. Jenis gambar yang digunakan adalah $R G B$ dengan beberapa dominan warna dan Grayscale. Cover image yang akan digunakan untuk pengujian disajikan pada Gambar 1. 


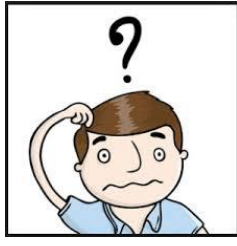

(a)

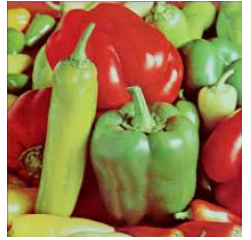

(b)

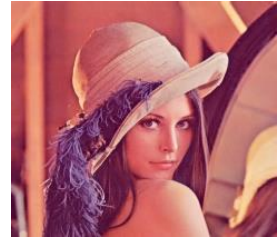

(c)

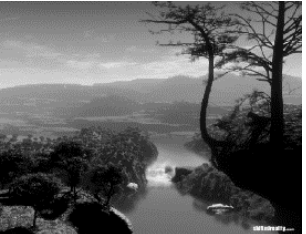

(d)

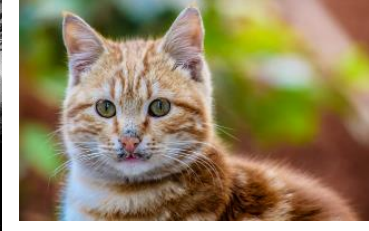

(e)

Gambar 1. Citra Cover (a) confused.png, (b) pepper.png, (c) lenna.png, (d) nature.png, (e) cat.png yang digunakan untuk eksperimen metode

\subsection{Flowchart Discrete Wavelet Transform}

Flowchart Discrete Wavelet Transform (DWT) merupakan tahapan -tahapan dalam melakukan denoising pada citra. Citra yang digunakan merupakan citra steganografi dengan format *.png. Tahapan - tahapan penyisipan pesan rahasia dan ekstraksi pesan dapat dilihat pada Gambar 2.

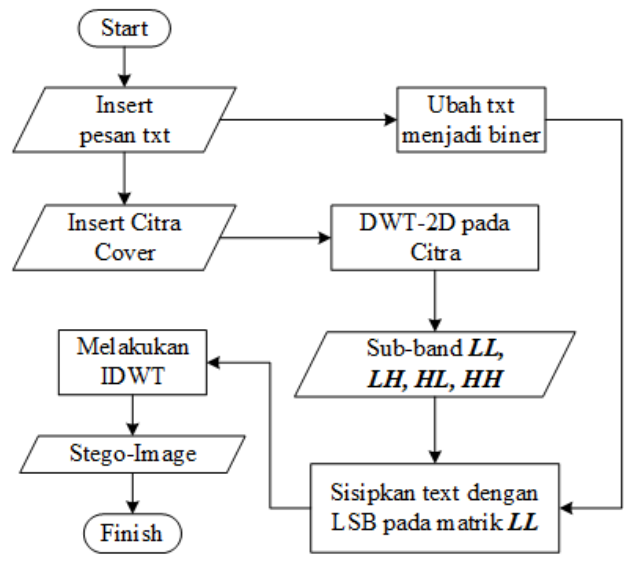

(a)

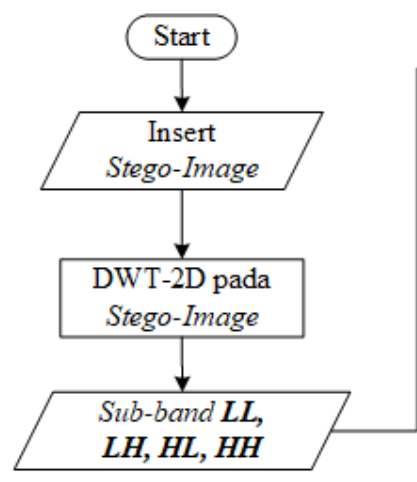

(b)

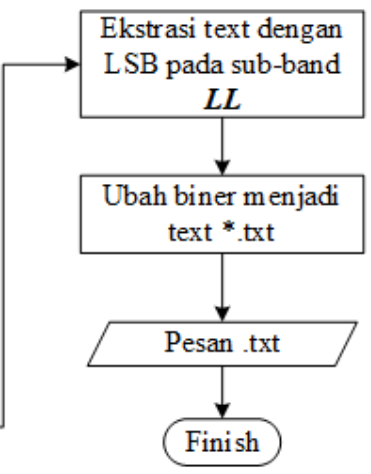

)

Gambar 2. Flowchart Penyisipan Pesan (a) dan Ekstraksi Pesan (b) pada Metode DWT

Langkah - langkah penyisipan pesan pada metode $D W T$ yang dilakukan pada penelitian ini adalah sebagai berikut :

1. Insert pesan *.txt dan citra sebagai cover image.

2. Ubah pesan *.txt menjadi biner

3. Menerapkan $D W T-2 \mathrm{D}$ pada citra menjadi 4 sub-band $\boldsymbol{L} \boldsymbol{L}, \boldsymbol{L H}, \boldsymbol{H L}$ dan $\boldsymbol{H} \boldsymbol{H}$.

4. Sisipkan pesan menggunakan LSB pada sub-band $\boldsymbol{L} \boldsymbol{L}$

5. Stego-image didapat menggabungkan matrik $\boldsymbol{L L s}, \boldsymbol{L H}, \boldsymbol{H L}$ dan $\boldsymbol{H} \boldsymbol{H}$ menggunakan rumus IDWT(LLs, $\boldsymbol{L} \boldsymbol{H}, \boldsymbol{H L}, \boldsymbol{H H})$ Matrik $\boldsymbol{L} \boldsymbol{L} \boldsymbol{s}$ merupakan matrik $\boldsymbol{L} \boldsymbol{L}$ yang telah disisipkan pesan rahasia.

Sedangkan untuk langkah - langkah ekstraksi pesan yang dilakukan pada penelitian ini untuk metode $D W T$ adalah sebagai berikut :

1. Insert stego-image

2. Lakukan DWT pada stego-image menjadi matrik $\boldsymbol{L} \boldsymbol{L}, \boldsymbol{L H}, \boldsymbol{L H}$ dan $\boldsymbol{H} \boldsymbol{H}$.

3. Ekstraksi pesan rahasia dengan LSB dari matrik $\boldsymbol{L} \boldsymbol{L}$

4. Pesan rahasia didapat dengan cara mengubah bilangan biner menjadi pesan *.txt.

\subsection{Flowchart Singular Value Decomposition}

Flowchart Singular Value Decomposition (SVD) merupakan tahapan -tahapan dalam melakukan penyisipan dan ekstraksi pesan pada citra. Citra yang digunakan merupakan citra steganografi dengan format *.png. Tahapan - tahapan penyisipan dan ekstraksi pesan pada citra dapat dilihat pada Gambar 3. 


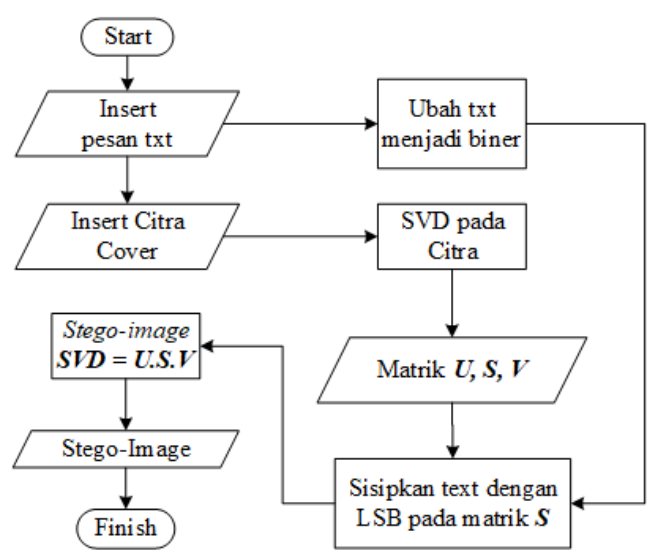

(a)

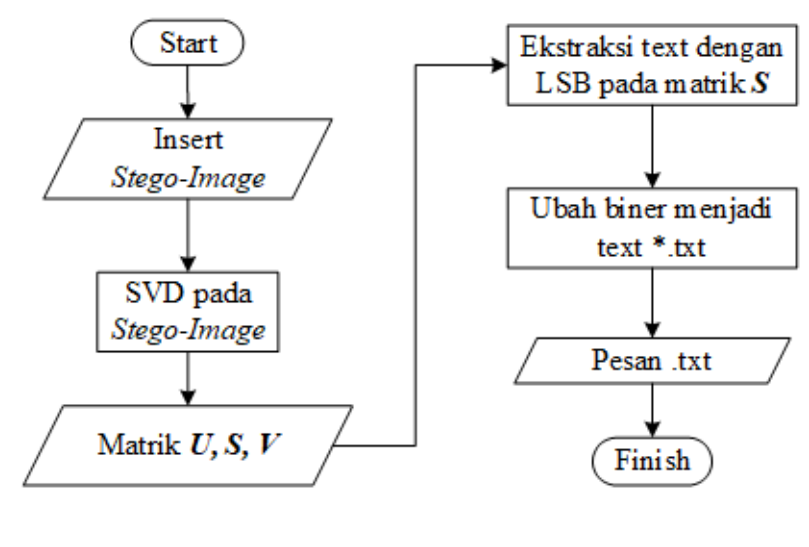

(b)

Gambar 3. Flowchart Penyisipan Pesan (a) dan Ekstraksi Pesan (b) pada Metode SVD

Langkah - langkah penyisipan pesan yang dilakukan pada penelitian ini untuk metode $S V D$ adalah sebagai berikut :

1. Insert pesan *.txt dan citra sebagai cover image.

2. Ubah pesan *.txt menjadi biner

3. Melakukan $S V D$ pada citra menjadi matrik $\boldsymbol{U}, \boldsymbol{S}$, dan $\boldsymbol{V}$.

4. Sisipkan pesan menggunakan LSB pada matrik $S$

5. Stego-image didapat menggabungkan matrik $\boldsymbol{U}, \boldsymbol{S}$, dan $\boldsymbol{V}$ menggunakan rumus $\boldsymbol{M}=$ $\boldsymbol{U}$. S. D Matrik $\boldsymbol{S}$ merupakan matrik yang telah disisipkan pesan rahasia.

Sedangkan langkah - langkah ekstraksi pesan pada penelitian yang dilakukan untuk metode $S V D$ adalah sebagai berikut :

1. Insert stego-image

2. Lakukan $S V D$ pada stego-image menjadi matrik $\boldsymbol{U}, \boldsymbol{S}$, dan $\boldsymbol{D}$.

3. Ekstraksi pesan rahasia dengan LSB pada matrik $\boldsymbol{S}$ dengan cara sebagai berikut:

4. Pesan rahasia didapat dengan cara mengubah bilangan biner menjadi pesan *.txt.

\subsection{Implementasi Program Metode DWT dan SVD}

Berdasarkan flowchart program pada Gambar 2 dan Gambar 3, selanjutnya tahapan yang dilakukan adalah mengimplementasikan metode ke dalam bahasa pemrograman python. Program dibuat berbasis console tanpa menggunakan Graphic User Interface (GUI). Gambar 4 dan Gambar 5 merupakan proses dari penyisipan pesan rahasia ke dalam cover image.

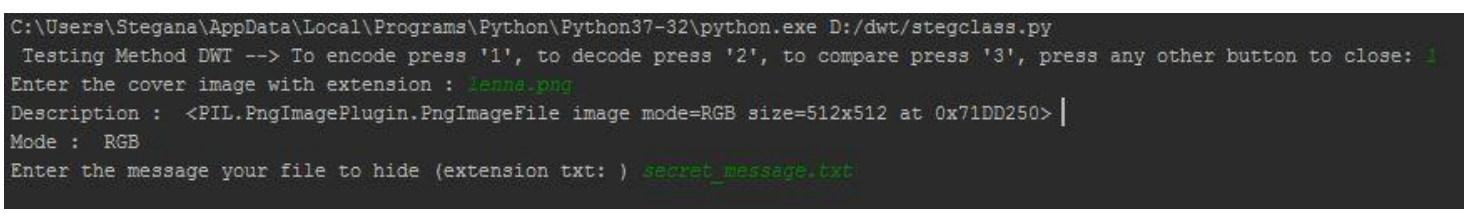

Gambar 4. Proses Penyisipan Pesan Metode DWT

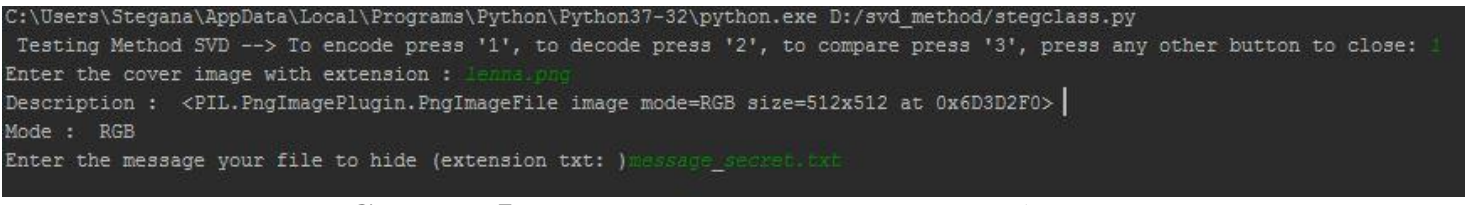

Gambar 5. Proses Penyisipan Pesan Metode SVD

Untuk melakukan proses encode atau penyisipan pesan ke dalam cover image, pengguna dapat mengetikkan angka "1", jika akan melakukan proses decode atau ekstraksi pesan pengguna 
dapat mengetikkan angka " 2 ", dan untuk membandingkan hasil antara metode $D W T$ dan SVD maka pengguna dapat mengetikkan angka " 3 ".

\section{HASIL DAN PEMBAHASAN}

\subsection{Hasil Pengujian}

Untuk mengukur kualitas citra pada stego image pada metode DWT dan SVD maka dilakukan pengujian menggunakan salah satu metode pengujian pada steganografi yaitu fidelity dengan cara menghitung nilai Mean Square Error (MSE) dan Peak Signal to Noise Ratio (PSNR) menggunakan persamaan (1) [18].

$$
\begin{aligned}
& M S E_{\mathrm{AVG}}=\frac{M S E_{\mathrm{R}}+M S E_{\mathrm{G}}+M S E_{\mathrm{B}}}{3} \\
& P S N R=10_{\log 10}\left(\frac{255^{2}}{M S E}\right)
\end{aligned}
$$

Cara kerja dari metode pengujian fidelity adalah membandingkan antara cover image dan stego image dan melihat perubahan sebelum dan sesudah pesan disisipkan ke dalam gambar. Skenario pengujian yang dilakukan adalah dengan menggunakan cover image yang disajikan pada Gambar 1 dengan format *.png dan untuk pesan rahasia disimpan pada file dengan format *.txt. Penerapan metode DWT dan SVD diuji cobakan pada bahasa Pemrograman Python 3 dengan alur logika program yang sesuai dengan flowchart pada Gambar 2 untuk metode DWT dan Gambar 3 untuk metode $S V D$. Hasil uji coba menggunakan fidelity untuk metode $D W T$ dan $S V D$ disajikan pada Tabel 1. Proses pengujian dilakukan dengan cara menggunakan cover image pada Gambar 1 dengan dimensi gambar yang sama yaitu ukuran 512 x 512 dan menggunakan pesan yang sama pada setiap dengan format $t x t$ dengan ukuran file $20 \mathrm{~KB}$.

\begin{tabular}{|c|c|c|c|c|c|c|c|}
\hline \multirow[t]{2}{*}{ Cover image } & \multirow{2}{*}{$\begin{array}{l}\text { Dimensi } \\
\text { Gambar }\end{array}$} & \multirow{2}{*}{$\begin{array}{l}\text { Ukuran } \\
\text { Pesan } \\
\text { (KB) }\end{array}$} & \multirow[t]{2}{*}{ Stego Image } & \multicolumn{2}{|c|}{ Metode $D W T$} & \multicolumn{2}{|c|}{ Metode $S V D$} \\
\hline & & & & $M S E$ & PSNR & $M S E$ & PSNR \\
\hline & $\begin{array}{c}512 \mathrm{x} \\
512\end{array}$ & 20 & & $\begin{array}{c}0.001 \\
\mathrm{db}\end{array}$ & $\begin{array}{c}66.214 \\
\mathrm{db}\end{array}$ & $\begin{array}{l}0.2 \\
\mathrm{db}\end{array}$ & $\begin{array}{c}42.3 \\
\mathrm{db}\end{array}$ \\
\hline & $\begin{array}{c}512 \mathrm{x} \\
512\end{array}$ & 20 & & $\begin{array}{c}0.005 \\
\mathrm{db}\end{array}$ & $\begin{array}{c}62.353 \\
\mathrm{db}\end{array}$ & $\begin{array}{l}0.3 \\
\mathrm{db}\end{array}$ & $\begin{array}{c}43.5 \\
\mathrm{db}\end{array}$ \\
\hline & $\begin{array}{c}512 \mathrm{x} \\
512\end{array}$ & 20 & & $\begin{array}{c}0.004 \\
\mathrm{db}\end{array}$ & $\begin{array}{c}64.116 \\
\mathrm{db}\end{array}$ & $\begin{array}{c}0.21 \\
\mathrm{db}\end{array}$ & $\begin{array}{c}43.16 \\
\mathrm{db}\end{array}$ \\
\hline & $\begin{array}{c}512 \mathrm{x} \\
512\end{array}$ & 20 & & $\begin{array}{c}0.006 \\
\mathrm{db}\end{array}$ & $\begin{array}{c}62.330 \\
\mathrm{db}\end{array}$ & $\begin{array}{c}0.25 \\
\mathrm{db}\end{array}$ & $\begin{array}{c}42.30 \\
\mathrm{db}\end{array}$ \\
\hline & $\begin{array}{c}512 \mathrm{x} \\
512\end{array}$ & 20 & & $\begin{array}{c}0.007 \\
\mathrm{db}\end{array}$ & $\begin{array}{c}62.330 \\
\mathrm{db}\end{array}$ & $\begin{array}{l}0.4 \\
\mathrm{db}\end{array}$ & $\begin{array}{c}41.40 \\
\mathrm{db}\end{array}$ \\
\hline
\end{tabular}

Tabel 1. Hasil Pengujian Fidelity untuk Metode DWT dan SVD

$\mathrm{db}=$ desibel.

Pada hasil pengujian yang disajikan pada Tabel 1 untuk metode $D W T$ menunjukkan nilai $M S E$ yang sangat baik yaitu rata-rata sudah mendekati angka 0 , artinya perubahan piksel yang dihasilkan pada metode $D W T$ pada stego image tidak terlalu banyak mengalami perubahan. Sedangkan untuk nilai PSNR yang dihasilkan rata-rata $60 \mathrm{db}$ dan sudah melebihi standar kualitas stego image yang baik yaitu lebih dari $40 \mathrm{db}$ [19] artinya kualitas citra yang dihasilkan pada 
metode $D W T$ sudah sangat baik. Sedangkan untuk metode SVD menghasilkan nilai MSE yang cukup baik juga yaitu rata-rata sudah mendekat angka 0 walaupun untuk cover image cat.png masih memiliki nilai MSE yaitu 0,4. Meskipun demikian, perubahan piksel yang dihasilkan pada metode $S V D$ pada stego image tidak terlalu banyak mengalami perubahan. Sedangkan untuk nilai PSNR yang dihasilkan rata-rata $42 \mathrm{db}$ dan sudah melebihi standar kualitas stego image yang baik yaitu lebih dari $40 \mathrm{db}$ artinya kualitas citra yang dihasilkan pada metode $S V D$ sudah cukup baik.

\subsection{Pembahasan}

Untuk melihat hasil perbandingan nilai $P S N R$ pada metode $D W T$ dan SVD disajikan dalam bentuk Grafik yang ada pada Gambar 6 .

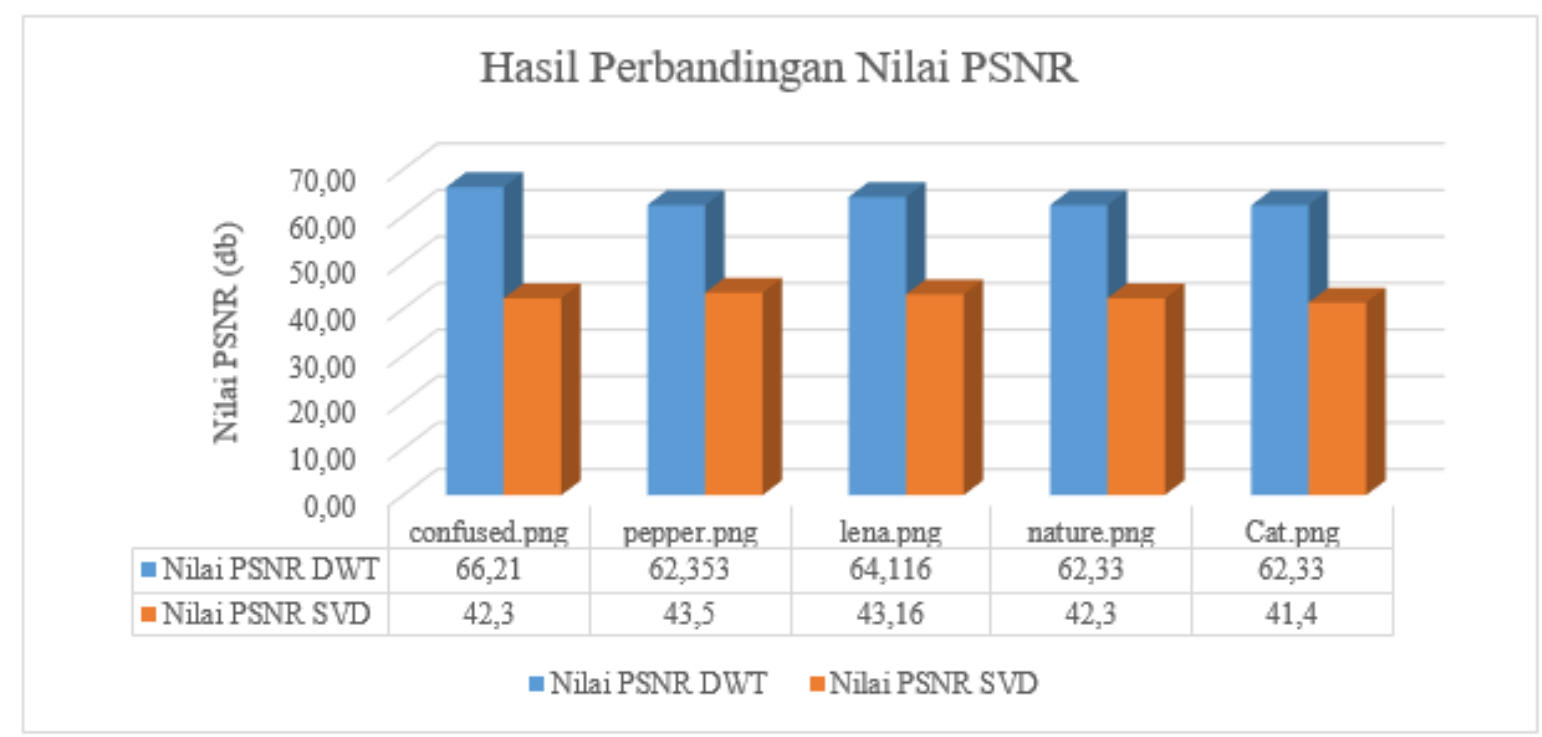

Gambar 6. Grafik Perbandingan Nilai PSNR metode DWT dan SVD

Pada grafik yang disajikan pada Gambar 6 menunjukkan bahwa metode $D W T$ dan $S V D$ memiliki nilai PSNR lebih dari $40 \mathrm{db}$, hal ini sudah menunjukkan kualitas citra yang dihasilkan oleh kedua metode tersebut sudah baik. Namun pada pengujian yang disajikan metode $D W T$ menghasilkan stego image dengan nilai PSNR lebih tinggi dibandingkan dengan metode SVD. Hal ini disebabkan karena pada metode $D W T$ transformasi yang dilakukan dengan memanfaatkan filter wavelet berdasarkan baris (horizontal) dan kemudian diikuti dengan filter berdasarkan kolom (vertikal) serta penggunaan Low Pas Filter (LPF) dan High Pass Filter (HPF) yang diterapkan pada program yang digunakan membuat kualitas citra yang dihasilkan menjadi lebih baik. Selain itu kombinasi metode Least Significant Bit (LSB) juga menjadi salah satu faktor dalam menghasilkan kualitas citra yang baik pada metode $D W T$ dan $S V D$.

\section{KESIMPULAN}

Metode $D W T$ dan $S V D$ pada penelitian ini diimplementasikan menggunakan bahasa pemrograman python 3 untuk proses penyisipan pesan dan ekstraksi pesan. Berdasarkan hasil pengujian yang dilakukan metode $D W T$ dapat menghasilkan kualitas citra pada stego image yang lebih baik jika dibandingkan metode $S V D$, hal ini dibuktikan pada hasil pengujian dengan menghitung nilai $M S E$ metode $D W T$ memiliki nilai yang lebih kecil jika dibandingkan metode $S V D$ yaitu dengan nilai rata-rata $0,0046 \mathrm{db}$. Hasil perhitungan nilai $P S N R$ juga membuktikan bahwa metode $D W T$ lebih baik jika dibandingkan metode $S V D$ yaitu menghasilkan nilai rata-rata $63,47 \mathrm{db}$. 


\section{UCAPAN TERIMAKASIH}

Ucapan terimakasih disampaikan kepada Kementerian Riset dan Teknologi / Badan Riset Inovasi Nasional Republik Indonesia yang telah memberikan bantuan dana Hibah Penelitian dengan No Kontrak 839/SP2H/LT/MONO/LL2/2020

\section{Daftar Pustaka}

[1] B. Mishra, R. Beg and V. P. Singh, "Information Security Through Digital Image Steganography Using Multilevel and Compression Technique," MIT International Journal of Computer Science \& Information Technology, vol. 3, 2016.

[2] N. B. Pamungkas, D. Darwis, D. Nurhayanti and A. T. Prastowo, "Perbandingan Algoritma Pixel Value Differencing dan Modulus Function pada Steganografi untuk Mengukur Kualitas Citra dan Kapasitas Penyimpanan," Jurnal Informatika, vol. 20, no. 1, pp. 67-77, 2020.

[3] D. Darwis, R. Prabowo and N. Hotimah, "Kombinasi Gifshuffle, Enkripsi AES dan Kompresi Data Huffman Untuk Meningkatkan Keamanan Data," Jurnal Teknologi Informasi dan Ilmu Komputer (JTIIK), vol. 5, no. 4, pp. 389-394, 2018.

[4] A. Suhendri, B. D. Juniansyah, M. J. Priono and D. Darwis, "Implementasi Kombinasi Affine Cipher dan One-time Pad Dalam Pengamanan Pengiriman Pesan," Jurnal Informatika, vol. 18, no. 2, pp. 124-129, 2018.

[5] M. S. Kachera, G. Gupta and N. Jain, "An Improved Noise Resistant Image Steganography Technique Using Zero Cross Edge Detection Method," International Research Journal of Engineering and Technology (IRJET), vol. 4, no. 3, 2017.

[6] D. Darwis and K. Kisworo, "Teknik Steganografi untuk Penyembunyian Pesan Teks Menggunakan Algoritma End Of File," Explore: Jurnal Sistem Informasi dan Telematika (Telekomunikasi, Multimedia dan Informatika), vol. 8, no. 2, pp. 98-108, 2017.

[7] D. Darwis, "Teknik Steganografi untuk Penyembunyian Pesan Teks Menggunakan Algoritma GIFSHUFFLE," Jurnal Teknoinfo, vol. 11, no. 1, pp. 19-24, 2017.

[8] C. Lai and C. Tsai, "Digital Image Watermarking using Discrete Wavelet Transform and Singular alue Decomposition," IEEE Transactions on Interumentation, vol. 15, 2020.

[9] H. S. M. Reddy, "High Capacity and Security Steganography using Discrete Wavelet Transform," International Journal of Computer Science and Security, vol. 3, 2010.

[10] Y. He, T. Gan, W. Chen and H. Wang, "Adaptive Denoising by SIngular Value Decomposition," IEEE, 2011.

[11] R. A. Nurfauzan, B. Hidayat and S. Saidah, "Analisis Steganografi Ganda Pada Citra Digital Menggunakan Metode Discrete Wavelet Transform Dan Singular Value Decomposition Dengan Penyisipan Spread Spectrum Image Steganography," in e-Proceeding of Engineering, 2018.

[12] S. Singh and T. J. Siddiqui, "Robust Image Steganography Using Complex Wavelet Transform," IEEE, 2013.

[13] Y. J. Chanu, K. M. Singh and T. Tuitung, "A Robust Steganographic Method Based on Singular Value Decompostion," International Journal of Information \& Computation Technology, vol. 4, 2014.

[14] D. Darwis, "Implementasi Steganografi pada Berkas Audio Wav untuk Penyisipan Pesan Gambar Menggunakan Metode Low Bit Coding," EXPERT, vol. 5, no. 1, pp. 6 - 11, 2015.

[15] A. Prawirawan, I. Isnawaty and R. Ramadhan, "Implementasi Discrete Wavelet Transform Untuk Penyisipan Teks Pada Gambar," Semantik, vol. 1, no. 1, pp. 11-18, 2015.

[16] Q. Guo, C. Zhang, Y. Zhang and H. Liu, "An Efficient SVD-Based Method for Image Denoising," IEEE, 2016. 
[17] D. Darwis, A. Junaidi and W. Wamiliana, "A New Approach of Steganography Using Center Sequential Technique," in Journal of Physics: Conference Series, Bandar Lampung, 2019.

[18] Awate and M. M. Patil, "Modulus Function and Pixel Value Differencing Coupled with Modified Pixel Indicator Based Secret Data Hidding Method," International Journal of Advances in Science Engineering and Technology, vol. 4, no. 2, pp. 26-29, 2016.

[19] B. Bhatu and H. y. Shah, "Customized Approach to Increase Capacity and Robustness in Image Steganography," Coimbatore, 2016. 